\title{
IMPLEMENTASI WEB LIVE WORKSHEET BERBASIS PROBLEM BASED LEARNING DALAM PEMBELAJARAN MATEMATIKA
}

\author{
Fatimatul Khikmiyah ${ }^{1}$ \\ Universitas Muhammadiyah Gresik ${ }^{1}$ \\ fatim@umg.ac.id ${ }^{1}$
}

\begin{abstract}
Abstrak
Pandemi covid-19 telah mengubah proses pembelajaran yang biasanya guru dan peserta didik bertemu langsung dalam kelas menjadi suatu pembelajaran dalam jaringan (online learning) tak terkecuali pembelajaran matematika. Karena tidak semua sekolah memiliki Learning Manajement System (LMS) dan kemampuan guru yang terbatas, maka pembelajaran banyak dilakukan melalui Whatsapp Grup dengan mengirim tugas dalam bentuk foto dan peserta didik juga mengirim jawabannya dengan cara yang sama. beban belajar peserta didik menjadi lebih berat karena mereka dituntut untuk mencermati dan mempelajari materi sendiri dengan cepat. Peserta didik menjadi kurang aktif dan cepat bosan pada pembelajaran. Meskipun guru memberikan ruang bertanya melalui chat namun hal ini dirasakan kurang efektif bagi peserta didik apalagi untuk materi yang bersifat abstrak seperti matematika.Salah satu alternatif yang dapat digunakan oleh guru untuk mengatasi permasalahan ini adalah dengan menggunakan lembar kerja peserta didik (LKPD) pada pembelajaran daring yang disebut Web Live Worksheet. LKPD ini diimplementasikan pada peserta didik Kelas VII-G di SMP N 6 Gresik, yang terletak di Jl. Kanjeng Sepuh Desa Mriyunan Kecamatan Sidayu Kabupaten Gresik, Provinsi Jawa Timur. Hasil penelitian ini menunjukkan bahwa implementasi Web liveworksheet berbasis Problem Based Learning ( $\mathrm{PBL}$ ) mampu meningkatkan aktifitas peserta didik pada pembelajaran matematika dalam jaringan dengan rata-rata keaktifan peserta didik sebesar 84 \%. Selain itu, kemampuan pemecahan masalah matematika peserta didik sebagian besar (76,92 \%) terletak pada kategori sangat baik.
\end{abstract}

Kata Kunci: Web Live Worksheet, PBL, Pembelajaran Matematika

\section{A. Pendahuluan}

Sejak diumumkan adanya warga Indonesia yang terkonfirmasi positif Covid pada tanggal 2 Maret 2020 oleh Presiden Republik Indonesia Joko Widodo maka pemerintah Indonesia telah mengambil sejumlah kebijakan untuk memutus rantai penularannya. Kebijakan utamanya adalah memprioritaskan kesehatan dan keselamatan masyarakat dengan bekerja, beribadah dan belajar dari rumah. Kebijakan ini tentu saja berdampak luar biasa khususnya bagi dunia pendidikan 
dasar dan menengah. Tanpa fasilitas yang memadai dan kompetensi yang cukup, orangtua, guru, dan peserta didik mau tidak mau harus melaksanakan pembelajaran jarak jauh.

UNESCO menyebutkan bahwa pandemi Covid-19 mengancam 577.305.660 pelajar dari pendidikan pra-sekolah dasar hingga menengah atas. Di level pendidikan dasar dan menengah pembelajaran jarak jauh ini banyak mengalami kendala secara teknis. Banyak sekolah yang tidak memiliki sistem pembelajaran daring (Learning Manajement System), kuota internet yang terbatas dan laptop atau handphone yang harus bergantian di rumah ketika ada anak yang sekolah lebih dari satu dalam satu rumah. Menyikapi hal ini, cara paling mudah yang paling banyak digunakan oleh guru adalah menggunakan aplikasi WhatsApp untuk melaksanakan proses pembelajaran.

Melalui WhatsApp, guru membuat grup kelas kemudian pembelajaran dilaksanakan melalui chat, mengirim materi berupa teks atau video dan dilanjutkan dengan memberi tugas pada peserta didik. Pada saat memberikan tugas dalam pembelajaran jarak jauh khususnya matematika, biasanya guru mengambil dari buku paket peserta didik atau menuliskan soal dan mengirim tugas berupa foto kemudian meminta peserta didik untuk mengerjakan di kertas dan meminta peserta didik mengirim foto yang berisi jawaban dari tugas mereka. Dengan pembelajaran seperti ini, beban belajar peserta didik menjadi lebih berat karena mereka dituntut untuk mencermati dan mempelajari materi sendiri dengan cepat. Peserta didik menjadi kurang aktif dan cepat bosan pada pembelajaran. Meskipun guru memberikan ruang bertanya melalui chat namun hal ini dirasakan kurang efektif bagi peserta didik apalagi untuk materi yang bersifat abstrak seperti matematika.

Salah satu alternatif yang dapat digunakan oleh guru untuk mengatasi permasalahan ini adalah dengan menggunakan lembar kerja peserta didik (LKPD) pada proses pembelajaran. LKPD adalah panduan bagi peserta didik untuk mempelajari suatu konsep sehingga peserta didik dapat memecahkan suatu masalah (Yulia, Buyung, \& Relawati, 2018). Penggunaan LKPD pada pembelajaran diharapkan dapat mendorong peserta didik agar menjadi lebih aktif, kreatif dan mengasah pemikiran kritis mereka ketika menyelesaikan masalah 
matematika. Penggunaan LKPD cetak yang biasanya kita temui pada pembelajaran tatap muka nampaknya kurang relevan dengan model pembelajaran jarak jauh seperti saat ini. Diperlukan LKPD yang dapat digunakan oleh guru dan peserta didik pada pembelajaran mode daring (dalam jaringan) dan LKPD online, Live Worksheets, adalah salah satu jawaban atas tantangan ini.

LKPD online menggunakan website ini, Live Worksheets, merupakan salah satu media berbantuan media elektronik yang didalamnya terdapat teks, gambar, animasi, dan video-video yang lebih efektif agar peserta didik tidak cepat merasa bosan. LKPD online dalam penelitian ini didefinisikan sebagai alat pembelajaran yang dirancang secara online berisi materi dan langkah kerja yang sistematis dan menarik untuk dapat mencapai tujuan pembelajaran yang diharapkan. Jika ditinjau dari manfaatnya LKPD online diharapkan dapat membuat proses pembelajaran menjadi lebih menarik daripada pembelajaran menggunakan LKPD berupa media cetak/kertas.

Untuk mengembangkan karakter pebelajar abad 21 maka satu model pembelajaran yang dapat diterapkan dalam pembelajaran daring adalah Model Pembelajaran Berbasis Masalah (Problem Based Learning). Model pembelajaran ini dimulai dengan penyajian masalah yang dekat dengan kehidupan peserta didik. Untuk menemukan penyelesaian permasalahan tersebut, peserta didik harus mengumpulkan informasi dan data dari berbagai sumber. Melalui proses pemecahan masalah ini, peserta didik dapat berpikir secara kritis dan sistematis untuk mengambil kesimpulan berdasarkan pemahamannya sendiri (Saharsa, Qaddafi, \& Baharuddin, 2018). Problem Based Learning merupakan model pembelajaran yang berlandaskan pada prinsip konstruktivisme yang menekankan keterampilan proses penyelesaian masalah (Vitasari, 2016)

Berdasarkan paparan pada bagian sebelumnya maka rumusan masalah dari penelitian ini adalah sebagai berikut:

Apakah penggunaan Live Worksheet berbasis Problem Based Learning mampu meningkatkan aktifitas belajar dan kemampuan memecahkan masalah matematika peserta didik?

Oleh karena itu, penelitian ini bertujuan untuk mendeskripsikan dampak implementasi Live Worksheet berbasis Problem Based Learning terhadap 
keaktifan belajar dan kepercayaan diri peserta didik pada pembelajaran matematika. Beberapa teori yang melandasi penelitian ini adalah sebagai berikut:

1. LiveWorksheet

Liveworksheets merupakan platform berbasis web yang bernama Liveworksheet.com. LKPD ini memanfaatkan teknologi baru yang diimplementasikan dalam dunia pendidikan karena dapat menghasilkan suara, menampilkan video bahkan menghasilkan pesan suara. LKPD online ini memungkinkan seseorang mengubah lembar kerja konvensional/tradisional menjadi lembar kerja online interaktif karena peserta didik dapat mengerjakan LKPD secara online dan mengirimkan langsung kepada gurunya. Bagi guru, hal ini dapat menghemat waktu, bagi peserta didik dapat memotivasi dan sangat bermanfaat bagi lingkungan karena dapat menghemat kertas. (https://www.liveworksheets.com). Tampilan awal live worksheet tampat pada gambar 1.

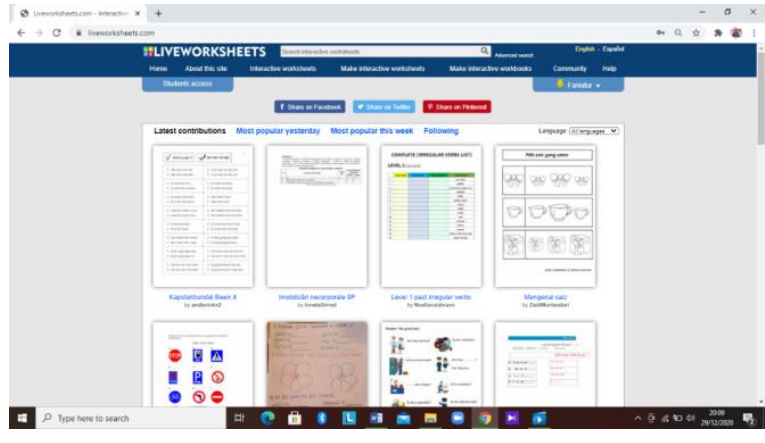

Gambar 1. Tampilan awal Live Worksheet

Prastowo (2013) menjelaskan bahwa setidaknya ada empat poin penting yang menjadi tujuan dari penyusunan LKPD yaitu, 1) menyajikan bahan ajar yang dapat mempermudah peserta didik pada saat berinteraksi dengan materi yang disampaikan, 2) menyajikan bermacam-macam tugas yang dapat meningkatkan penguasaan materi peserta didik, 3) mempermudah guru dalam memberikan tugas kepada peserta didik dan 4) melatih peserta didik untuk belajar secara mandiri.

Selain itu, Arsyad (2011) menjelaskan bahwa manfaat dari penggunaan LKPD dalam pembelajaran adalah, 1) memancing peserta didik berpartisipasi aktif dalam proses pembelajaran, 2) membantu peserta didik dalam mengembangkan konsep, 3) melatih peserta didik untuk menemukan serta 
mengembangkan keterampilan proses, 4) melatih peserta didik dalam pemecahan masalah berfikir kritis, 5) menghemat waktu mengajar.

\section{Pembelajaran Berbasis Masalah (Problem Based Learning/PBL)}

Roh (2003, p.2) menyatakan bahwa pembelajaran berbasis masalah adalah pembelajaran yang dimulai dengan suatu masalah yang harus diselesaikan. Masalah tersebut diajukan sedemikian hingga peserta didik akan memerlukan pengetahuan baru untuk menyelesaikan masalah tersebut. Tidak sekedar trial dan error, peserta didik akan menafsirkan masalah yang diberikan, mengumpulkan informasi yang diperlukan, mengidentifikasi alternatif penyelesaian, menilai pilihan yang mungkin dan menarik kesimpulan.

Menurut Abidin (2014) karakteristik dari model PBL adalah, 1) masalah menjadi starting point dalam pembelajaran, 2) masalah yang digunakan bersifat konseptual, 3) permasalahan tersebut dapat mendorong kemampuan peserta didik dalam berpendapat, 4) permasalahan tersebut dapat mengembangkan pengetahuan, sikap, keterampilan, dan kompetensi peserta didik, 5) berorientasi pada pengembangan belajar secara mandiri, 6) memanfaatkan berbagai sumber belajar, 7) pembelajaran yang menekankan komunikatif, aktivitas, kolaboratif, dan kooperatif, 8) menekankan pentingnya keterampilan meneliti, menentukan solusi dari permasalahan, dan penguasaan pengetahuan.

\section{Keaktifan Peserta Didik pada Pembelajaran Berbasis Masalah}

Dalam Kamus Besar Bahasa Indonesia, keaktifan dimaknai sebagai kegiatan atau kesibukan. Azevedo, diSessa dan Sherin (2012) mendefiniskan keaktifan peserta didik dalam pembelajaran sebagai intensitas dan kualitas partisipasi dalam kegiatan pembelajaran. Dalam pandangan mereka, keaktifan adalah sesuatu yang dapat diamati oleh observer.

Tahapan Pembelajaran Berbasis Masalah dalam penelitian ini yaitu:

Tahap 1 : Orientasi peserta didik terhadap masalah

Tahap 2 : Mengorganisasikan peserta didik untuk belajar

Tahap 3 : Membimbing proses penyelidikan individual maupun kelompok

Tahap 4 : Pengembangan dan penyajian hasil karya 
Tahap 5 : Analisis dan evaluasi proses pemecahan masalah

Sumber: (Kemendikbud, 2013)

Berdasarkan tahapan pembelajaran tersebut, maka aktifitas peserta didik pada pembelajaran daring menggunakan Web Live Worksheet adalah:

1) Peserta didik mengajukan pertanyaan kepada guru

2) Peserta didik menjawab pertanyaan guru

3) Peserta didik mengerjakan LKPD PBL menggunakan web Liveworksheet yang diberikan oleh guru melalui link

4) Kehadiran peserta didik pada saat pembelajaran

\section{Kemampuan Menyelesaikan Masalah}

Dalam pembelajaran matematika, pemecahan masalah menjadi fokus dan isu yang sangat menarik selama beberapa dekade (NCTM, 2000). Pemecahan masalah matematika selalu menjadi bagian dari penilaian yang dilakukan oleh OECD (Organization for Economic Corporation and Development) dalam PISA (Programme for International Students Assessment) yaitu program penilaian pelajar internasional tingkat dunia yang diselenggarakan dengan siklus tiga tahunan.

Gunantara (2014) menjelaskan bahwa yang dimaksud dengan kemampuan pemecahan masalah adalah kecapakan atau potensi yang dimiliki seseorang dalam menyelesaikan permasalahan dan mengaplikasikan dalam kehidupan sehari - hari. Sedangkan Solso dan Maclin (2014) menyatakan bahwa pemecahan masalah adalah suatu pemikiran yang terarah secara langsung untuk menentukan solusi atau jalan keluar atas suatu masalah yang spesifik. Indikator Kemampuan memecahkan masalah dalam penelitian ini mengacu pada Polya (1973:5) yang menyatakan bahwa untuk menyelesaikan suatu masalah, diperlukan empat langkah penyelesaian yaitu:

a. Memahami masalah (Understand The Problem)

b. Merencanakan penyelesaian (Devise a Plan)

c. Melaksanakan rencana (Carry Out The Plan)

d. Memeriksa kembali (Looking Back) 


\section{B. Metode Penelitian}

Penelitian ini dilaksanakan di SMP N 6 Gresik, yang berada di Jl. Kanjeng Sepuh Desa Mriyunan Kecamatan Sidayu Kabupaten Gresik, Provinsi Jawa Timur. Subyek penelitian ini sebanyak 26 peserta didik kelas VII-G yang terdiri dari 13 laki-laki dan 13 perempuan. Adapun waktu penelitian yaitu pada semester genap tahun ajaran 2020/2021. LKPD model problem based learning dengan menggunakan web liveworksheets ini dimaksudkan untuk meningkatkan aktivitas belajar dan kemampuan memecahkan masalah matematika peserta didik.

Metode pengambilan data yang digunakan dalam penelitian ini yaitu metode observasi untuk mencari data tentang keaktifan peserta didik sedangkan metode tes digunakan untuk mencari data tentang hasil belajar peserta didik. Adapun instrumen yang digunakan yaitu lembar observasi dan lembar tes kemampuan pemecahan masalah matematika. Lembar observasi aktifitas peserta didik memuat 4 (empat) aktifitas dan observer diminta menuliskan banyaknya peserta didik yang aktif atau tidak aktif pada tiap kategori. Sedangkan instrumen tes kemampuan pemecahan masalah matematika terdiri dari 4 (empat) soal uraian. Seluruh instrumen telah divalidasi oleh 2 (dua) validator yaitu Dosen Prodi Pendidikan Matematika Universitas Muhammadiyah Gresik dan guru matematika. Dari hasil validasi kedua validator diperoleh, rata-rata dari seluruh aspek penilaian instrumen kemampuan pemecahan masalah matematika sebesar 3,75 dan berada pada kategori valid.

Metode analisis keaktifan peserta didik menggunakan persentase, yaitu banyaknya peserta didik yang memenuhi kategori aktif atau tidak aktif sedangkan untuk kemampuan pemecahan masalah matematika menggunakan kategori sebagai berikut:

Tabel 1. Kategori Kemampuan Pemecahan Masalah Matematika Peserta Didik

\begin{tabular}{clc}
\hline No & \multicolumn{1}{c}{ Kategori } & Nilai \\
\hline 1 & Tinggi & $\geq 75$ \\
2 & Sedang & $60 \leq$ nilai $<75$ \\
3 & Rendah & $<60$ \\
\hline
\end{tabular}




\section{Hasil dan Pembahasan}

LKPD berbasis web Live Worksheet dengan PBL ini diimplementasikan pada materi aritmatika sosial yaitu bruto, netto dan tara. Implementasi LKPD pada pembelajaran dilakukan selama 2 (dua) pertemuan dengan durasi 60 menit menyesuaikan jadwal pembelajaran pada saat pandemi. Proses pembelajaran dilakukan menggunakan aplikasi Google Classroom dan LKPD diberikan oleh guru pada kegiatan inti yang dimulai dengan orientasi peserta didik pada masalah. Guru memberikan link LKPD kepada peserta didik dan mengarahkan peserta didik untuk membuka dan melaksanakan pembelajaran menggunakan LKPD tersebut.

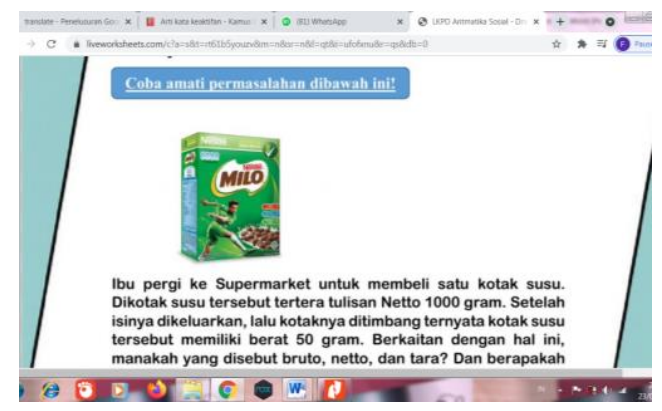

Gambar 2 . Tampilan Live Worksheet pada tahap orientasi terhadap masalah Tabel di bawah ini menyajikan rekapitulasi hasil observasi aktifitas peserta didik pada proses pembelajaran menggunakan Web Live Worksheet dengan PBL.

Tabel 2. Hasil Persentase Aktivitas Peserta Didik Kelas VII-G

\begin{tabular}{|c|c|c|c|c|c|c|c|c|c|}
\hline \multirow{4}{*}{ No } & \multirow{4}{*}{ Aktivitas } & \multicolumn{8}{|c|}{ Jumlah Peserta Didik } \\
\hline & & \multicolumn{4}{|c|}{ Pertemuan I } & \multicolumn{4}{|c|}{ Pertemuan II } \\
\hline & & \multicolumn{2}{|c|}{ Aktif } & \multicolumn{2}{|c|}{ Tidak Aktif } & \multicolumn{2}{|c|}{ Aktif } & \multicolumn{2}{|c|}{ Tidak Aktif } \\
\hline & & $\mathbf{\Sigma P D}$ & $\%$ & EPD & $\%$ & $\mathbf{\Sigma P D}$ & $\%$ & $\mathbf{\Sigma P D}$ & $\%$ \\
\hline 1 & A & 18 & $69 \%$ & 8 & $31 \%$ & 20 & $77 \%$ & 6 & $23 \%$ \\
\hline 2 & B & 15 & $58 \%$ & 11 & $42 \%$ & 17 & $65 \%$ & 9 & $35 \%$ \\
\hline 3 & $\mathrm{C}$ & 26 & $100 \%$ & 0 & $0 \%$ & 26 & $100 \%$ & 0 & $0 \%$ \\
\hline 4 & $\mathrm{D}$ & 26 & $100 \%$ & 0 & $0 \%$ & 26 & $100 \%$ & 0 & $0 \%$ \\
\hline & Jumlah & & $327 \%$ & & $73 \%$ & & $342 \%$ & & $58 \%$ \\
\hline & ta-rata tiap & & $81 \%$ & & $19 \%$ & & $86 \%$ & & $14 \%$ \\
\hline
\end{tabular}




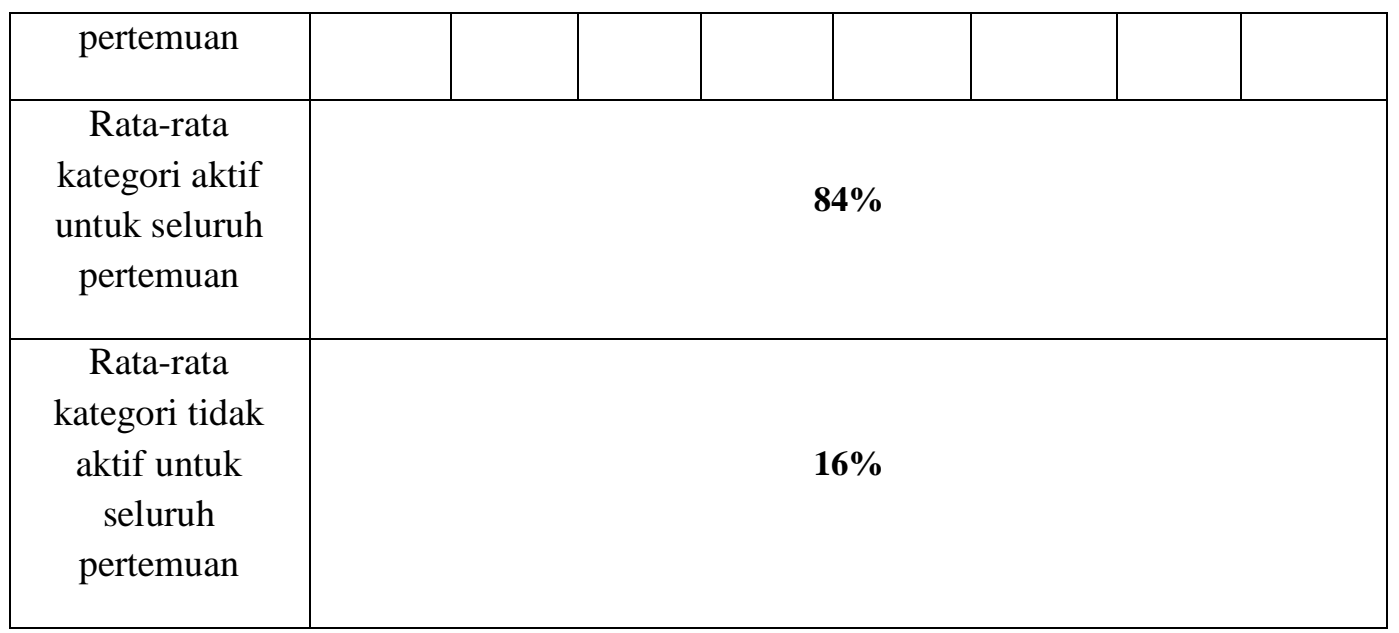

Keterangan:

Aktivitas A : Peserta didik mengajukan pertanyaan kepada guru

Aktivitas B : Peserta didik menjawab pertanyaan guru

Aktivitas C : Peserta didik mengerjakan LKPD PBL menggunakan web Liveworksheet yang diberikan oleh guru melalui link

Aktivitas D : Kehadiran peserta didik pada saat pembelajaran

Tabel 2 menjelaskan bahwa pada pertemuan pertama, peserta didik yang berada di kategori aktif sebesar $81 \%$ dan kategori tidak aktif 19\%. Pada pertemuan kedua peserta didk yang berada di kategori aktif naik menjadi $88 \%$ dan yang berkategori tidak aktif menjadi 14\%. Dengan demikian rata-rata untuk kategori aktif dari seluruh pertemuan adalah $84 \%$ sedangkan pada kategori tidak aktif pada seluruh pertemuan adalah 16\%. Berdasarkan rincian aktifitasnya, semua peserta didik hadir pada proses pembelajaran sedangkan aktifitas dengan jumlah peserta didik paling sedikit yaitu.menjawab pertanyaan yang diajukan oleh guru.

Selain aktifitas peserta didik, penelitian ini juga bertujuan untuk mendeskripsikan kemampuan peserta didik dalam menyelesaikan masalah matematika khusunya pada materi bruto, netto dan tara. Berdasarkan analisis hasil tes kemampuan pemecahan masalah peserta didik maka diperoleh hasil sebagai berikut: 
Tabel 3. Kategori Kemampuan Pemecahan Masalah Matematika

Peserta Didik

\begin{tabular}{clcc}
\hline No & Kategori & Jumlah Peserta Didik & Persentase \\
\hline 1 & Tinggi & 20 & $76,92 \%$ \\
2 & Sedang & 5 & $19,23 \%$ \\
3 & Rendah & 1 & $3,85 \%$ \\
\hline
\end{tabular}

Tabel menunjukkan bahwa sebagian besar peserta didik (76,92 \%) memiliki kemampuan pemecahan masalah matematika tinggi, 19,23\% peserta didik berkemampuan pemecahan masalah matematika sedang dan hanya 1 (satu) peserta didik yang memiliki kemampuan pemecahan masalah matematika rendah.

Untuk menggali lebih dalam tentang respon peserta didik terhadap penggunaan Web Live Worksheet berbasis PBL pada pembelajaran daring maka dilakukan wawancara kepada 3 (tiga) peserta didik masing-masing dari kategori kemampuan matematika tinggi, sedang dan rendah. Dari wawancara tersebut diperoleh hasil bahwa seluruh peserta didik menyatakan bahwa menggunakan LKPD online adalah hal yang baru bagi mereka sehingga mereka sangat tertarik untuk mengikuti pembelajaran. Selanjutnya 2(dua) anak menyatakan bahwa penggunaan LKPD ini menambah motivasi mereka dalam belajar matematika sekaligus membantu mereka dalam memahami materi aritmatika sosial. Dari sisi waktu, peserta didik mengumpulkan LKPD yang sudah diisi pada waktu yang cepat. Hal ini sangat jauh berbeda dengan kondisi sebalumnya di mana guru harus menunggu sampai malam jawaban atau hasil dari tugas yang diberikan kepada peserta didiknya.

Hasil penelitian ini sejalan dengan pendapat Chen (2017) yang menjelaskan bahwa pada banyak penelitian, pembelajaran menggunakan bantuan komputer atau semacamnya terbukti efektif dalam meningkatkan hasil belajar peserta didik dan meningkatkan minat dan sikap positif terhadap pembelajaran. Sikap positif yang tampak pada perilaku peserta didik yaitu tingkat partisipasi mereka yang sangat tinggi dalam proses pembelajaran dan mengerjakan LKPD PBL menggunakan web Liveworksheet yang diberikan 
oleh guru. Tingkat keaktifan yang tinggi ini nampaknya berdampak pada pencapaian kemampuan pemecahan masalah matematika yang tinggi. Hal ini dimungkinkan terjadi karena peserta didik mengikuti dengan baik proses pemecahan masalah yang disajikan pada web Liveworksheet sehingga menjadi suatu pembiasaan dalam memecahkan masalah matematika.

\section{Kesimpulan}

Berdasarkan hasil penelitian yang dipaparkan pada bagian sebelumnya, peneliti menyimpulkan bahwa implementasi Web liveworksheet berbasis Problem Based Learning (PBL) mampu meningkatkan aktifitas peserta didik pada pembelajaran matematika dalam jaringan dengan rata-rata keaktifan peserta didik sebesar $84 \%$. Selain itu, kemampuan pemecahan masalah matematika peserta didik sebagian besar (76,92 \%) terletak pada kategori sangat baik. Dengan demikian, Web Live Worksheet ini dapat menjadi salah satu alternatif yang dapat digunakan oleh guru dalam meningkatkan keaktifan dan kemampuan pemecahan masalah matematika terutama untuk pembelajaran dalam jaringan.

\section{Daftar Pustaka}

Abidin. (2014). Desain Sistem Pembelajaran dalam Konteks Kurikulum 2013. Bandung: Refika Aditama.

Azevedo, F. S., diSessa, A. A., \& Sherin, B. L. (2012). An evolving framework for describing student engagement in classroom activities. The Journal of Mathematical Behavior, 31(2), 270-289.

Azhar, Arsyad. (2004). Media Pembelajarani. Jakarta: Raja Grafindo.

Chen, K. T. (2017). An exploratory study of NNES graduate students' reading comprehension of English journal articles. Reading in a Foreign Language, 29(1), 20-35.

Gunantara, dkk. (2014). Penerapan Model Pembelajaran Problem Based Learning untuk Meningkatkan Kemampuan Pemecahan Masalah Matematika Siswa Kelas V. Jurnal Mimbar PGSD Universitas Pendidikan Ganesha Jurusan PGSD, Vol.2(1).

Polya. G. (1973). How To Solve (2nd Ed). Princeton: University Press. 
Prastowo, A. (2013). Pengembangan Bahan Ajar Tematik. Yogyakarta : Diva Press.

Roh, Kyeong Ha. (2003). Problem Based Learning in Mathematics (pp 1-7): ERIC Digest

Saharsa, U., Qaddafi, M., \& Baharuddin. (2018). Efektivitas penerapan Model Pembelajaran Problem Based Learning Berbantuan Video Based Laboratory Terhadap Peningkatan Pemahaman Konsep Fisika. Jurnal Pendidikan Fisika , 6 (2), 57-64.

Solso, Maclin \& Maclin. (2014). Cognitive Psychology. (8th Ed). Edinburg: Pearson Education Limited

Yulia, S., Buyung, B., \& Relawati, R. (2018). Pengembangan Lembar Kerja Siswa (LKS) Berbasis Problem Based Learning Pada Materi Bilangan di Kelas VII SMP Negeri 22 Kota Jambi. PHI: Jurnal Pendidikan Matematika, 2(1), 192-204 